University of Nebraska - Lincoln

DigitalCommons@University of Nebraska - Lincoln

Spiders (Araneae) Collected as Prey by the Mud-Dauber Wasps Sceliphron caementarium and Chalybion californicum (Hymenoptera: Sphecidae) in Southeastern Nebraska1

Tyler B. Corey

Earl Agpawa

Eileen Hebets

Follow this and additional works at: https://digitalcommons.unl.edu/bioscihebets

Part of the Animal Sciences Commons, Behavior and Ethology Commons, Biology Commons, Entomology Commons, and the Genetics and Genomics Commons

This Article is brought to you for free and open access by the Papers in the Biological Sciences at DigitalCommons@University of Nebraska - Lincoln. It has been accepted for inclusion in Eileen Hebets Publications by an authorized administrator of DigitalCommons@University of Nebraska - Lincoln. 


\title{
Spiders (Araneae) Collected as Prey by the Mud-Dauber Wasps Sceliphron caementarium and Chalybion californicum (Hymenoptera: Sphecidae) in Southeastern Nebraska ${ }^{1}$
}

\author{
Tyler B. Corey², Earl Agpawa, and Eileen A. Hebets
}

University of Nebraska-Lincoln, School of Biological Sciences, 402 Manter Hall, Lincoln, Nebraska 68588 USA

\section{J. Entomol. Sci. 56(2): 123-140 (April 2021)}

\begin{abstract}
Predator diets represent a potential interaction between local prey availability, prey antipredator defenses, and predator foraging behavior. Female spider-specialist muddauber wasps (Hymenoptera: Sphecidae) collect spiders and provision them intact, but paralyzed, to their developing larvae, providing a unique means of quantifying the diversity and abundance of prey that they capture. Mud-dauber wasps are hypothesized to be a major source of selection on antipredator defenses in web-building spiders, and the spiny and thickened abdomens of female spiny orb-weaving spiders (Araneae: Araneidae) are hypothesized to function as antiwasp defenses. We inventoried spider prey from nests of the mud-dauber wasps Sceliphron caementarium (Drury) and Chalybion californicum (Saussure), and surveyed for spider fauna in areas surrounding nest collection sites, to specifically investigate if the spiny orb-weaver Micrathena gracilis (Walckenaer) was collected as prey by these wasps. We collected nests from six sites in southeastern Nebraska from two regions that we classify based on habitat-a forest corridor and agricultural land. We collected 761 intact spider prey from 87 nests and identified them to the family level. None of these spiders were $M$. gracilis. Micrathena gracilis were rare in faunal surveys on agricultural land and, surprisingly, absent in forest corridor surveys. Mud-dauber wasps were more common; we collected more spiders on agricultural land than in the forest corridor. We propose that in agricultural landscapes, the lack of certain spiders in mud-dauber wasp nests is driven by habitat use differences between predators and prey rather than physical antipredator defenses.
\end{abstract}

Key Words antipredator defenses, predation, habitat use

Understanding the diversity and quantity of prey in predator diets is critical in understanding how predators affect the structure of ecological communities (Navarrete and Manzur 2008) and the expression of prey traits (Large and Smee 2013). When a given predator species is found across a wide geographic range, the abundance and distribution of prey types (and traits) across this range can vary in response to local environmental conditions that influence habitat type and structure (Toja and Sota 2006, Terraube and Arroyo 2011). The types of prey present in different habitat types also can differ in their antipredator defenses which, in turn, affects their potential profitability to predators (Brodie et al. 2002). Thus, predators

\footnotetext{
${ }^{1}$ Received 07 April 2020; accepted for publication 27 April 2020.

${ }^{2}$ Corresponding author (Tylercorey13@gmail.com).
} 
with broad geographic ranges may experience a range of potential prey types that vary in their antipredator defenses, and they may alter predator foraging behavior accordingly (Simpfendorfer et al. 2001). From an empirical perspective then, the presence (or absence) of prey from predator diets represents a potential interaction of local prey availability, prey antipredator defenses, and predator foraging behavior (Reeve et al. 2009).

Geographically widespread spider-specialist mud-dauber wasps (Hymenoptera: Sphecidae) (e.g., Sceliphron, Chalybion, Trypoxylon) provide a unique means of studying predator-prey interactions through their bizarre life histories (Bohart and Menke 1976). Individual female wasps collect tens to hundreds of spiders and provision them intact, but paralyzed, to their developing larvae in mud-nests (reviewed in Coville 1987, O'Neill 2001). Mud-dauber wasps can be locally abundant (Hunt 1993) and may have significant impacts on spider communities. Indeed, mud-dauber wasps are hypothesized to be a major source of selection on antipredator defenses in web-building spiders (Blackledge et al. 2003). The differences in foraging and nest-building behavior across mud-dauber species is related to differences in the types of spider prey that they capture (Uma and Weiss 2009), and multiple mud-dauber species may be found in a given area. Inventories of different species of mud-dauber wasp nests from a given area, therefore, can provide a glimpse into local spider abundance, diversity, and biogeography (Crawford 1986, Dean et al. 1988, Dorris 1969, Muma and Jeffers 1945, Volkova et al. 1999)-even the spread of invasive species (E. Powell and L. Taylor, University of Florida, unpubl. data).

Inventories of mud-dauber wasp nests, however, can reflect biases in the foraging behavior of individual wasps and/or avoidance of particular spider species despite their abundance (Powell and Taylor 2017). It is, therefore, important to pair nest inventories with independent faunal surveys of potential spider prey (Blackledge et al. 2003). Combining these approaches helps us better understand how local spider abundance and diversity-and potential antipredator defenses-affect the representation of spider prey in mud-dauber wasp nests and, thus, wasp foraging behavior (Dean et al. 1988, Gonzaga and Vasconcellos-Neto 2005, Jocqué 1988, Polidori et al. 2007, Uma et al. 2013).

Female spiny orb-weavers (Araneae: Araneidae: Actinacantha, Gasteracantha, Macracantha, Micrathena, Thelacantha) are hypothesized to have evolved antiwasp antipredator defenses. Females of many Micrathena (Sundevall) species have thickened, sclerotized opisthosoma cuticle and spines that are hypothesized to have evolved (at least in part) under selection from mud-dauber wasp predators (Elgar and Jebb 1999, Magalhães and Santos 2012). Several lines of inferential evidence inform the hypothesis that sclerotized opisthosoma cuticle and spines function as antiwasp defenses. Even where they are abundant, for example, spiny orb-weavers are rarely found in mud-dauber wasp nests, especially in comparison with other orb-weaving spiders (Gonzaga and Vasconcellos-Neto 2005). Only seven juvenile Micrathena gracilis (Walckenaer), for example, were collected among $>2,000$ other individual araneids in Sceliphron caementarium (Drury) nests sampled during one reproductive season (Muma and Jeffers 1945). In another study, while another species of spiny orb-weaver, Gasteracantha cancriformis (L.), was found in Sceliphron laetum (Smith) mud-dauber wasp nests, these spiny orbweavers were provisioned only later in the sequence of larval development. The 
authors hypothesized that only larger wasp larvae are capable of digesting the spider's thickened cuticle (Elgar and Jebb 1999). Some species of Sceliphron muddauber wasps, however, appear to specialize on spiny orb-weavers. Micrathena were the overwhelming majority of prey in nests sampled by Gonzales-Bustamante (1994; Sceliphron spp.) and Camillo (2002; Sceliphron fistularium (Dahlbom)), including two nests that each contained >120 Micrathena spp. in the former study.

In a prior study (T.B.C. et al. unpubl. data), we used visual modeling to explore whether the spiny orb-weaver $M$. gracilis is conspicuous to wasp predators through achromatic vision, which is used in long-distance object and movement detection (Osorio and Vorobyev 2005). Our results suggest that wasps should readily detect $M$. gracilis. Similar results from that study and another suggest that female $M$. gracilis are conspicuous to and defended against jumping spiders (T.B.C. unpubl. data), and conspicuous to and difficult to digest for avian predators (T.B.C. and E.A.H. unpubl. data). Since $M$. gracilis should be visually conspicuous to wasps, we were interested in determining whether mud-dauber wasps gather $M$. gracilis to provision their offspring. Most studies to date suggest that $M$. gracilis are successful in avoiding predation by a variety of predators and, thus, we predicted that despite their conspicuousness, muddauber wasps would not provision their nest cells with $M$. gracilis.

In order to test this prediction, we explored the diversity and quantities of spider prey provisioned in nests by the mud-dauber wasps $S$. caementarium and Chalybion californicum (Saussure) in eastern Nebraska. In conjunction with these nest inventories, we also performed faunal surveys for spiders to estimate spider population density (as a measurement of prey availability) at a subset of collection sites. We compared the representation of $M$. gracilis found in our faunal surveys to the representation of $M$. gracilis in the mud-dauber nests that we inventoried. Since $M$. gracilis are locally abundant in deciduous forests in Lincoln, NE (in which we have conducted prior field research; T.B.C. pers. obs.), we predicted that $M$. gracilis would be common in our faunal surveys, but that they would be underrepresented (or even absent entirely) as prey in mud-dauber nests compared with other spiders.

We inventoried mud-dauber wasp nests from two different regions that differ in their proximity to deciduous forest and agricultural land habitats. One region was a forest corridor (Wilderness Park, Lincoln, NE) that is otherwise surrounded by plains and farmland. The other region (Wittstruck Road, Martell, NE) is primarily made up of private residences on agricultural land and prairie. We provide additional data and inferences on the natural history of wasps in the area, specifically in reference to wasp phenology and the incidence of nest parasitism across sites.

Study system. The nesting and provisioning behavior of the mud-dauber wasps $S$. caementarium and $C$. californicum have been thoroughly studied by inventorying thousands of spiders collected from their nests across the United States (e.g., Muma and Jeffers 1945). Both of these mud-dauber wasp species have large geographic ranges and can be found syntopically (Bohart and Menke 1976, Dean et al. 1988). Females of both species capture spiders by stinging them in the sternum with paralytic venom and carry them to their nests. Female wasps then store intact spiders within individual mud-nest cells about 3-4 cm long (Shafer 1949). After achieving a particular prey mass threshold for a nest cell (Elgar and Jebb 1999), a female wasp lays a single egg in the cell and seals the cell entrance. The egg hatches into a larva, which eventually consumes the spiders, metamorphoses into 
an adult, and emerges from the nest either in the current reproductive season or after winter diapause (Rau 1915). Female wasps then mate and begin building and provisioning mud nests.

Female $S$. caementarium build new mud nests one cell at a time after mating (Peckham and Peckham 1898, Rau 1935), whereas female C. californicum reuse and modify old mud nests built by $S$. caementarium and other syntopic muddaubers (Kurczewski 2003, Rau 1928). Sceliphron caementarium forages for webbuilding spiders by flying into their webs-potentially prompting spiders to move and/or drop from webs-and then searching for the spiders on the ground; or by invading silk retreats of spiders (Eberhard 1970). Chalybion californicum mimics the vibration of prey in spider webs, luring them in, and then stings spiders when they approach (Blackledge and Pickett 2000). The differences in foraging and nesting behavior of these two species potentially relate to differences in diet- $S$. caementarium is reported to often collect two-dimensional orb-weaving spiders (e.g., Family Araneidae), whereas $C$. californicum often collect three-dimensional web-building spiders (e.g., Family Theridiidae; Uma and Weiss 2009). Both species will collect cursorial, or ground-dwelling, spiders (e.g., Family Thomisidae, Salticidae; Muma and Jeffers 1945). That being said, the proximity of spiders to a mud-dauber's nest (Obin 1982), learned prey preferences based on local spider availability (Powell and Taylor 2017), and chemical cues from spiders (Uma and Weiss 2009) have also been shown to affect mud-dauber wasp prey choice.

Given recent studies showing considerable between-individual diet variation within these species (Powell and Taylor 2017), generalizations about species-level foraging preferences are becoming increasingly difficult to make. Our current data further support that such taxa-specific expectations for prey capture by $S$. caementarium and $C$. californicum may not be immediately straightforward. Therefore, inventories of mud-dauber nests across sites continue to enhance our understanding of the ecological impacts of these widespread predators, and simultaneously strengthen our understanding of spider communities.

\section{Materials and Methods}

Spider inventories. We collected mud-dauber wasp nests from multiple sites in eastern Nebraska over two summers (2018-2019) to identify spider prey provisioned to developing wasp larvae. We found that nests are abundant on human-made structures on and near farmland, while we were unable to find any nests in the deciduous forest habitat through preliminary surveys. We focused on $S$. caementarium and $C$. californicum nests because the overwhelming majority of the nests that we found were provisioned by these two species. We collected nests between 30 July and 10 August in 2018 and on 3 September in 2019.

We collected mud-dauber wasp nests from six sites. Two sites (Sites A and B) fell within the "Forest Corridor" region, which includes a 596-ha city park (Wilderness Park, Lincoln, NE) corridor surrounded by developed urban and agricultural landscapes and prairies ( $n=17$ nests). Site A was a privately owned, forested property adjacent to Wilderness Park with multiple sheds and open-air structures. Site B was a maintenance station in Wilderness Park operated by Lincoln Parks \& Recreation, which had several buildings and covered work areas. 
We also collected mud-dauber wasp nests from three sites (Sites C, D, and E) along Wittstruck Road, an agricultural and residential region in Martell, NE (hereafter "Agricultural Land"). These sites were all private properties on or adjacent to farmland, which each had multiple human-made structures including barns, sheds, garages, and houses ( $n=78$ nests).

All forest corridor sites were within a 1.5-km radius of Global Positioning System (GPS) coordinate N40 40'05.9', W96 46 $50.7^{\prime \prime}$. All agricultural land sites were within $1.5 \mathrm{~km}$ of GPS coordinate N40 $40^{\prime} 05.9^{\prime \prime}$, W96 $46^{\prime} 50.7^{\prime \prime}$ for the Agricultural Land regions. We do not provide specific GPS coordinates of these collection sites to protect the privacy of those property owners.

We collected nests that were within our reach using a ladder or stepstool from the walls and ceilings of barns, sheds, and garages (all less than about $12 \mathrm{~m}$ from the ground). To remove nests from the surface on which they were built, we used a butter knife or putty scraper. We selectively collected nests where we could identify at least one closed, identifiable nest cell, which could potentially contain developing wasps and/or spider prey. We assumed that these nests were being provisioned by wasps in the current reproductive season. We did not collect old, degraded nests that contained only broken and/or open nest cells from which wasps had emerged or been preyed on (Coward and Matthews 1995).

We collected and inventoried 87 mud-dauber wasp nests from our sites over two collection seasons (2018 and 2019). We dissected nests by using hard forceps to break open the cells. We separated out individual spiders and developing wasps from unidentifiable prey remains using soft forceps. We identified individual spiders to the family level following Ubick et al. (2005). We identified only spiders that were mostly intact (e.g., paralyzed spiders that had not been consumed by wasps). In some cases, we could identify partially consumed spiders that still had the prosoma and opisthosoma intact. However, we could not confidently identify all intact spiders to the family level. For spiders we could not identify, we added them to our counts of spider prey and classified them as "Unknown" ( $n=13$ spiders).

Many nests contained developing wasps. Any cells containing developing wasps did not contain identifiable spiders, because the spiders had already been consumed. We recorded the number of developing wasps that we found. We preserved all spiders and wasps in $70 \%$ ethanol and kept them in the Hebets Lab collection at the University of Nebraska-Lincoln.

Multiple nests had been colonized by nest parasites. We recorded all observed incidences of parasitism, identifying the parasite taxa where possible. We were able to determine parasitism based on the presence of parasite eggs, parasite molts, very small emergence holes at nest cell openings, empty yet identifiable muddauber wasp pupal cases, and metamorphosed adult parasites (T. Blackledge and M. Headlee, The University of Akron, pers. comm.).

Where possible, we identified the species of wasp that provisioned each nest based on (a) the presence of un-eclosed, metamorphosed adult wasps in the nest, and (b) characters of nest structure (see Muma and Jeffers 1945, O'Neill 2001 for photographs). Specifically, we assume that $S$. caementarium provisioned a nest if all of the nest cells were sealed, since $S$. caementarium build entirely new nests each breeding season. We assume that $C$. californicum provisioned a nest if one or more sealed cells were present among open nest cells, and/or if nest cells made of differently colored mud were built on the exterior of a nest containing open cells. 
Chalybion californicum modify and reuse old nests from which wasps had eclosed in prior reproductive seasons. If we could not use these aforementioned characters, we excluded those nests from our reports of species-specific prey capture.

We used (nonparametric) Wilcoxon rank sum tests to compare differences across the two collection regions (forest corridor versus agricultural land) in the total number of spiders collected per nest and the number of developing wasps per nest. We pooled together nests sampled in the 2018 and 2019 collection seasons, but only included those nests containing identifiable spiders $(n=25)$ or developing wasps $(n=37)$ in their respective analyses.

Spider faunal surveys. We paired nest inventories with faunal surveys from two sites-one per region (forest corridor and agricultural land) - to compare the representation of potential spider prey in nature to those collected by mud-dauber wasps (e.g., Gonzaga and Vasconcellos-Neto 2005). Solitary wasps and bees are known to forage at long distances away from their nests (a maximum of 1,200 m away for Xylocopa violacea (Molitor), a solitary bee in a similar size range as $S$. caementarium and C. californicum; reviewed in Gathmann and Tscharntke [2002]). Only two of our field sites had deciduous forest patches (preferred habitat for $M$. gracilis as per Biere and Uetz [1981], Hodge [1987]) that were within this maximum foraging distance, given the predominance of open agricultural landscape surrounding Lincoln, NE.

At our two different faunal survey sites (Property A for Wilderness Park, Property E for Wittstruck Road), we established two 50-m-long transects along which we performed repeated faunal surveys. The two transects were arranged in a straight line, with a 10-m-long gap between the ends of the two transects. During a given survey, we visually searched for spiders at and below eye level (approximately $2 \mathrm{~m}$ above ground). We also used a sweep net in the low vegetation. We surveyed within an approximately 1-m-wide buffer area along each side of the transect. Each transect, therefore, represented approximately $100-\mathrm{m}^{2}$ area and approximately $200-\mathrm{m}^{3}$ survey volume, with a total of approximately $200 \mathrm{~m}^{2}$ of survey area and approximately $400-\mathrm{m}^{3}$ survey volume per site. We counted and released spiders collected through sweep netting every $10 \mathrm{~m}$ along the survey transect. We left spiders identified in visual surveys undisturbed.

Since we were particularly interested in if $M$. gracilis were captured as prey from these areas, and due to time and survey effort constraints, we only identified spiders in the field during surveys as being $M$. gracilis or not, and then released them. We unfortunately did not identify any non- $M$. gracilis even to the family level.

We surveyed at each transect site three times, on three different days in the reproductive season of $M$. gracilis (9 July, 23 July, and 7 August 2018). All surveys took place between approximately 10:00 a.m. and 2:00 p.m. In each survey, we counted the number of female and male $M$. gracilis, and the number of non- $M$. gracilis spiders. We measured the availability of potential spider prey as spider population density (number of spiders $/ \mathrm{m}^{3}$ ), calculated as the total number of spiders found within a transect divided by the volume of that surveyed transect. We used this measure of density since spiders occupy three-dimensional habitat in nature.

We compared spider population density across forest corridor and agricultural land regions using a Wilcoxon rank sum test, pooling together data across faunal surveys within each region over the course of the reproductive season. We then used a Kruskal-Wallis test to examine potential within-region changes in spider 
population density over three time points in the reproductive season-9 July ("Early July"), 23 July ("Mid-July"), and 7 August ("Early August") 2018. We qualitatively discuss the representation of $M$. gracilis and non-M. gracilis prey collected during faunal surveys to the representation of prey found during nest inventories, since we did not find any $M$. gracilis in mud-dauber nests and found $M$. gracilis at only one of our two survey sites (and only eight $M$. gracilis at the other survey site).

\section{Results}

Spider inventories. We collected 87 mud-dauber wasp nests across the 2018 $(n=74)$ and $2019(n=17)$ reproductive seasons (Table 1). Mud-dauber wasps exclusively collected spiders as prey, as we found no non-spider taxa in wasp nest cells aside from known non-spider nest parasites.

We identified 761 spiders from seven different families (Araneidae, Linyphiidae, Oxyopidae, Philodromidae, Salticidae, Theridiidae, and Thomisidae) from 25 muddauber wasp nests (Table 2). More than half of these spiders were theridiids (405 spiders), and nearly a third of identified spiders were araneids (211 spiders). We also found linyphiids frequently ( 80 spiders), followed by thomisids (40 spiders). Spiders from the remaining families were rare in nests (six Salticidae, one Oxyopidae, and one Philodromidae). We also found 13 spiders that could be counted as individuals but not identified to the family level.

Mud-dauber wasp nests from the forest corridor region $(n=9)$ contained significantly fewer spiders per nest than those from the agricultural land region $(n=$ 15; Fig. 1a; Wilcoxon rank sum test, $W=25, P=0.01$ ). In further examining the two spider families with the most prey, there were no significant differences between regions in the number of araneids (Wilcoxon rank sum test, $W=42, P=0.13$ ) or theridiids (Wilcoxon rank sum test, $W=59, P=0.62$ ) collected per mud-dauber wasp nests. We did not find any $M$. gracilis or related spiny orb-weavers in any of our inventoried mud-dauber wasp nests.

We could confidently identify 5 S. caementarium nests and 12 C. californicum nests (Table 3 ). Most of the spiders from $S$. caementarium nests were theridiids (30 of 39 spiders). Theridiidae also was the most common family of prey collected by $C$. californicum (104 of 196 spiders), and we also collected a large number of linyphiids from these nests (76 of 196 spiders).

We found 18 developing wasps in nests from the forest corridor ( $n=10$ nests) and 99 developing wasps in nests from agricultural lands $(n=22$ nests). Individual nests from the forest corridor contained fewer developing wasps per nest when compared to nests from agricultural lands, although this difference was not significant (Fig. 1b; Wilcoxon rank sum test, $W=25, P=0.08$ ).

We found 14 mud-dauber nests with evidence of parasitism; these parasites included dermestids (Order Coleoptera), melittobia wasp larvae (Order Hymenoptera), and an adult cuckoo wasp (Order Hymenoptera, Family Chrysididae). We found parasitized nests from both agricultural lands and the forest corridor. The proportion of nests with parasites from those sites that we sampled in both 2018 and 2019 (Sites C and E, both on agricultural land) was noticeably different-while none of the 2018 nests contained parasites, more than half of the 2019 nests contained parasites (Table 1). 


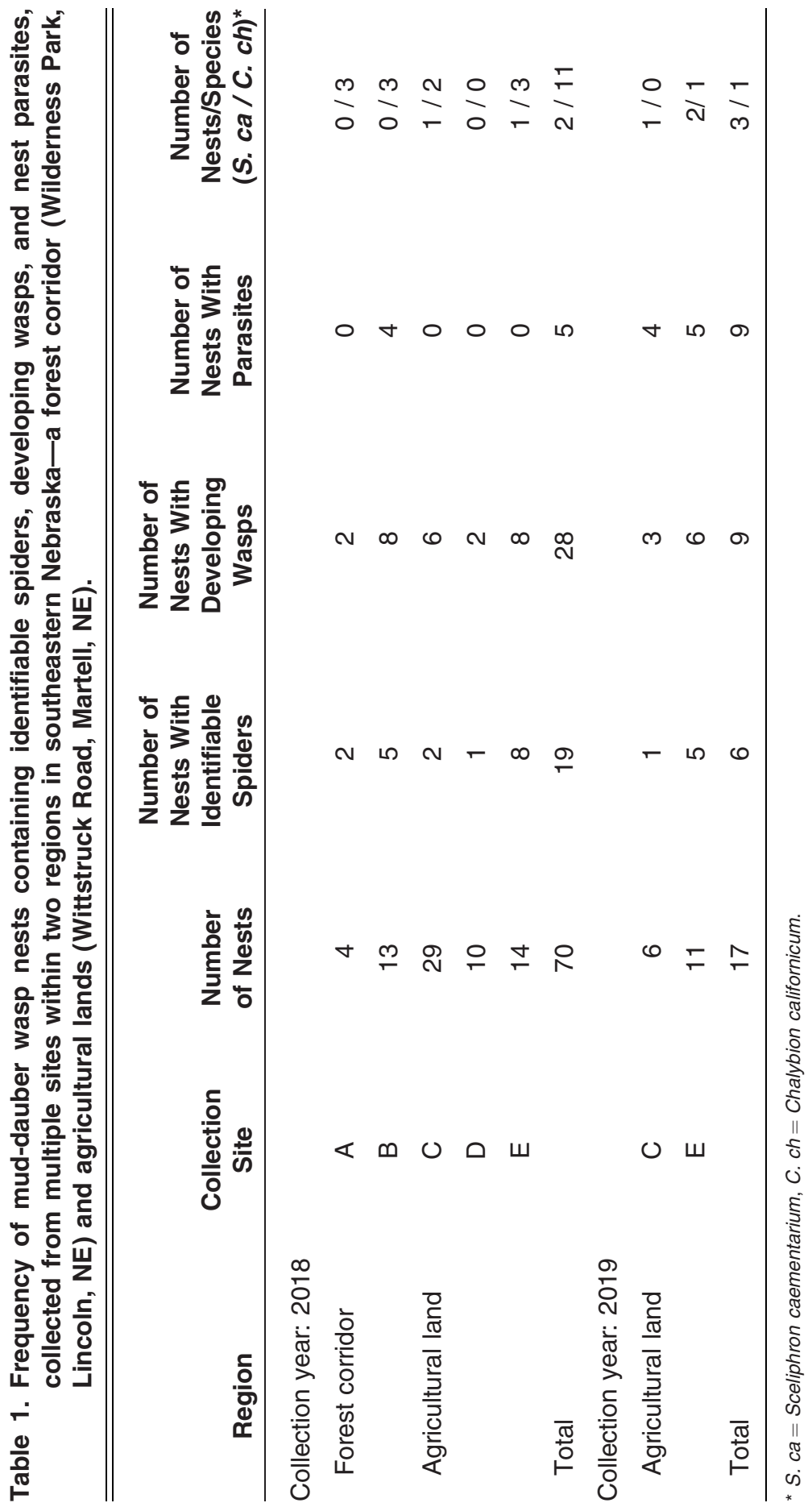




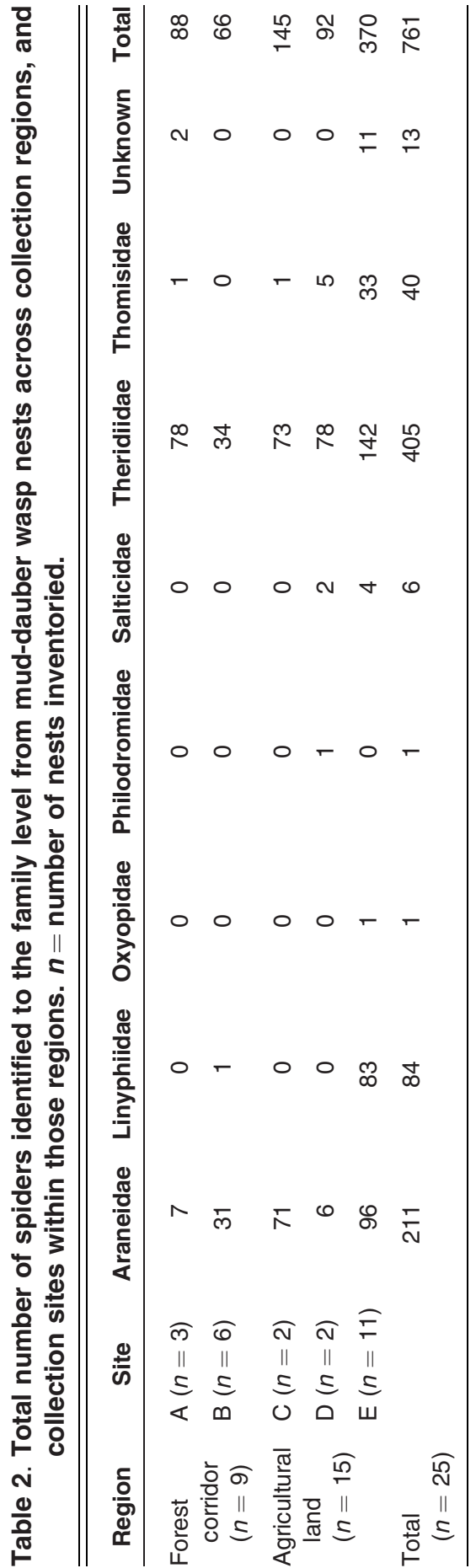



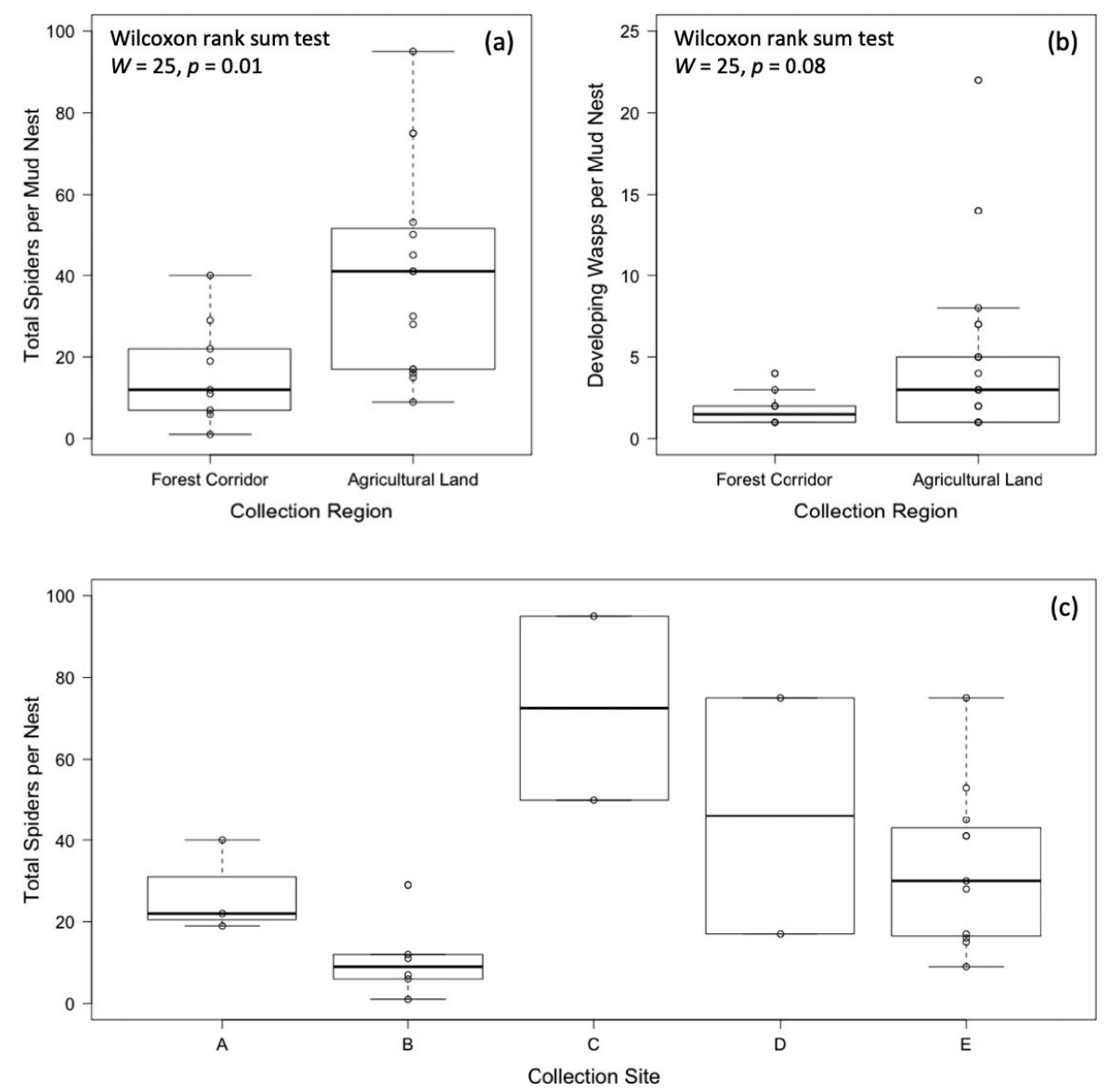

Fig. 1. The number of (a) identifiable spiders and (b) developing wasps found per individual mud-dauber wasp nest collected from forest corridor and agricultural land sites in southeastern Nebraska. (c) The total number of identifiable spiders per mud nest across all collection sites. Sites A and B were in the forest corridor, while Sites C, D, and E were on agricultural lands.

Spider faunal surveys. Spider population density was lower along the forest corridor transects than the agricultural land transects (Fig. 2), but this trend was not significant (Wilcoxon rank sum test, $W=330.5, P=0.07$ ). We collected an average of 39.6 spiders per survey in the forest corridor, and an average of 50 spiders per survey on agricultural land. Spider population density did not change over the wasp reproductive season within the forest corridor (Kruskal-Wallis test, $\chi^{2}=2.41, \mathrm{df}=2$, $P=0.30$ ) or on agricultural land (Kruskal-Wallis test, $\chi^{2}=5.38$, $\mathrm{df}=2, P=0.07$ ). We found only eight $M$. gracilis across three faunal surveys on agricultural land, but we never found $M$. gracilis during our faunal surveys in the forest corridor. 


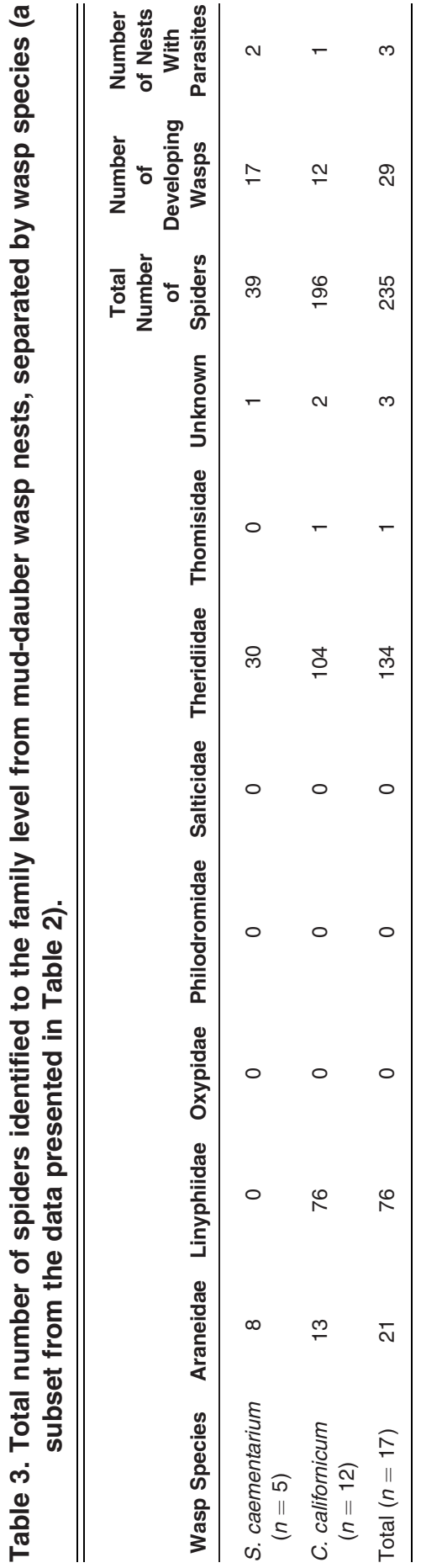




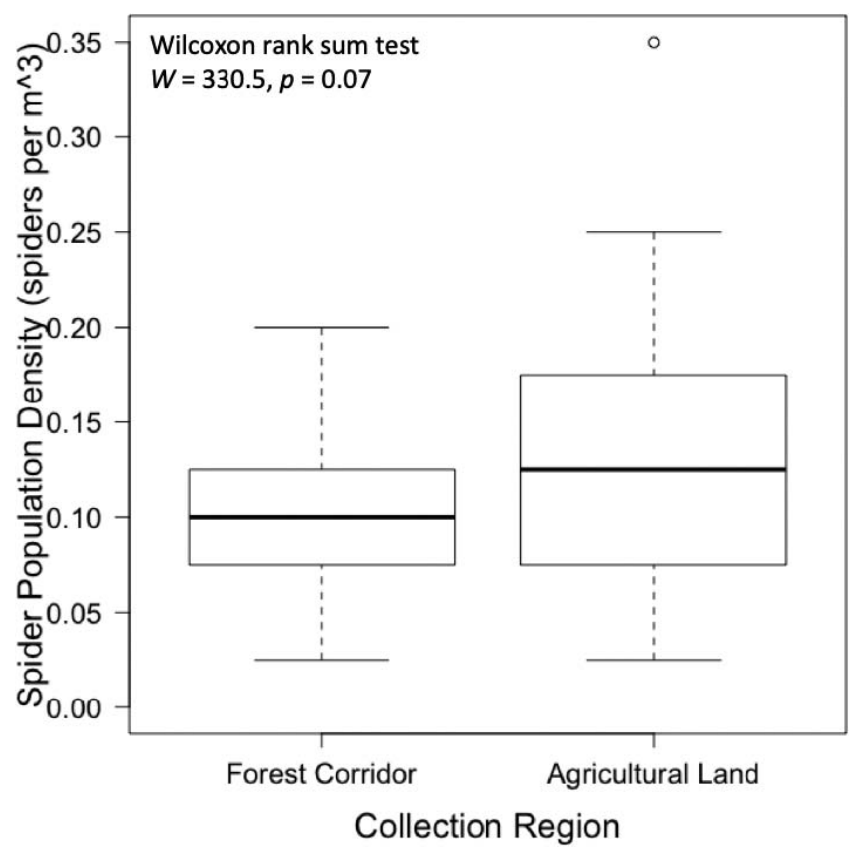

Fig. 2. Spider population density along transects in forest corridor and agricultural land sites in southeastern Nebraska.

\section{Discussion}

We found theridiids and araneids as common spider prey in mud-dauber wasp nests from southeastern Nebraska, but found no evidence for wasp predation on $M$. gracilis. By inventorying these nests, we also explored the diversity and abundance of spiders in forest corridors and agricultural lands in this area. We identified 761 spiders from seven taxonomic families. Mud-dauber wasps nesting in agricultural areas collected more spiders than those wasps nesting in a forest corridor. However, we found no differences between these regions in the numbers of theridiids and araneids provisioned per nest. We also found more developing wasps per nest from agricultural areas. Spider population density did not significantly differ between our survey regions, though there was a nonsignificant trend for more spiders on agricultural lands.

The representation of prey in mud-dauber nests varied across spider taxonomic families. We found large numbers of spider prey from the families Theridiidae and Araneidae. This is consistent with prior studies reporting that $C$. californicum often collect theridiids and S. caementarium often collect araneids (Muma and Jeffers 1945, Polidori et al. 2007, Uma and Weiss 2009). Unfortunately, we could not confirm the wasp species that were provisioning many of these nests, so our data are limited in their ability to support prior assertions of species differences in foraging patterns. 
For those nests that we could confirm were provisioned by either $S$. caementarium or C. californicum (5 and 12 nests, respectively), we found some notable prey selection patterns by individual wasps. For example, we found a $C$. californicum nest that contained 40 theridiids, consistent with prior studies reporting that these wasps preferentially collect three-dimensional web-building spiders (Muma and Jeffers 1945). On the other hand, we found 30 spiders, all of which were theridiids, in one $S$. caementarium nest. Sceliphron caementarium are expected to avoid collecting three-dimensional web building spiders (Muma and Jeffers 1945, Uma and Weiss 2009), although individual S. caementarium are known to specialize on particular prey based on their local availability (Powell and Taylor 2017). Notably, spiders from other taxa could have been collected as prey in these nests, but been consumed previously by developing wasp and, thus, gone unseen in our inventory.

Anecdotally, spiders from families that we found in high numbers per muddauber wasp nest were smaller than those found in lower numbers per nest. Specifically, theridiid and linyphiid prey were generally smaller than araneid and thomisid prey found in the nests we inventoried (T.B.C. and E.A. pers. obs.). Muddauber wasps are known to provision cells based on the total mass of spiders per cell, so smaller spiders can be collected in greater numbers than larger spiders to provide sufficient food resources to developing larvae (Elgar and Jebb 1999). Therefore, our results support earlier studies suggesting that mud-dauber wasp predators can have differential impacts on spider taxa based on spider size and web-building behavior (Blackledge et al. 2003).

We expect that wasps were likely foraging in areas aside from (or in addition to) those that we surveyed, since some other orb-weaver genera (Family Araneidae) were present in nest inventories but rare or absent in our faunal surveys. Specifically, we found Argiope spp. and Araneus spp. in mud-dauber nests (T.B.C. and E.A. pers. obs.), but we never collected Argiope and rarely found other large araneids in our faunal surveys (T.B.C. pers. obs.). Argiope trifasciata (Forsskål) and A. aurantia (Lucas) are abundant in prairie areas in and around Lincoln, NE (E.A.H. and E.A. pers. obs.), and are likely found and collected by mud-dauber wasps in and near agricultural areas as well (Horton and Wise 1983, Ramirez and Haakonsen 1999). Coudrain et al. (2013) report that Trypoxylon figulus (L.) muddauber wasps nesting in agricultural areas will forage in adjacent stands of deciduous forest, and Obin (1982) suggested that mud-daubers are less likely to collect spiders in the immediate proximity of their nests. Future studies might, therefore, encompass larger areas for faunal surveys, or begin by identifying wasp foraging locations through focal observations.

As we predicted, we did not find any $M$. gracilis or related spiny orb-weavers in mud-dauber wasp nests. However, we found so few $M$. gracilis in our faunal surveys-only 8 of 157 spiders from agricultural land, and 0 of 119 spiders in the forest corridor-that their absence in mud-dauber wasp nests could be explained primarily by differences in their local abundance and habitat preferences (Polidori et al. 2007). Simply put, M. gracilis and mud-dauber wasps did not appear to overlap in our study areas.

Mud-dauber wasps build nests abundantly in human-made structures, especially in barns and sheds, commonly found on agricultural land (Hunt 1993; Polidori et al. 2005, 2007). We collected 74 nests from human-made structures on agricultural 
land, but only 17 nests from structures in the forest corridor. The abundance of nests in human-made structures on agricultural land could reflect more than the ease of detecting nests, but also the wasps' temperature preferences. Mud-dauber wasps depend on reaching high body temperatures in order to achieve flight, which is essential for their foraging (O'Neill 2001). These wasps not only have to carry themselves through the air, but they also have to carry their paralyzed spider prey, which can be even larger than the wasps themselves (Elgar and Jebb 1999). When collecting mud-dauber wasps nesting in small garden sheds for a field enclosure experiment (from Site D, a private property on agricultural land; T.B.C. unpubl. data), we found that many wasps were actively flying and foraging for spiders by approximately 9:00 a.m. on hot (approximately $27^{\circ} \mathrm{C}$ and above) and sunny days. In contrast, wasps were rarely active on cooler, cloudier days, or when it was raining (T.B.C. pers. obs.). After collecting mud-dauber wasps for several hours and returning to our enclosures in the deciduous forest corridor, wasps in the enclosure were often inactive, and the temperature was noticeably cooler. We frequently attempted to observe wasps in the enclosures in the morning (from 9:00 a.m. onward), and even on warm and sunny days, these wasps were typically inactive until the mid- to late afternoon. The lower activity levels of wasps in the forest corridor could help explain why these wasps appear to nest less frequently and collect fewer spiders in this region compared with agricultural lands.

In contrast to the potentially heat-seeking wasps, $M$. gracilis are most commonly found in shaded areas within deciduous forests (Biere and Uetz 1981). In fact, female $M$. gracilis will actively move from habitat types with higher sun exposure to more shaded areas (Hodge 1987). Thus, it may not be surprising that we did not find many $M$. gracilis in deciduous forests adjacent to our wasp nest collection sites. In Lincoln, NE-and likely other regions with agricultural activity and permanent structures-deciduous forest habitat patches (where M. gracilis can be abundant) are uncommon near farmland. In fact, our two faunal survey sites that we identified were the only locations in our area where we could find both suitable M. gracilis habitat, and also feasibly collect mud-dauber wasp nests. In preliminary surveys conducted throughout deciduous forest habitat in Wilderness Park, $M$. gracilis were common, but we were never able to find mud-dauber nests despite observing foraging wasps on several occasions (T.B.C. pers. obs.).

We expected that the forest patches we established as survey sites would be suitable $M$. gracilis habitat, given that in prior seasons (and even the same season) we were able to find $M$. gracilis abundantly in nearby areas. It was surprising to find no $M$. gracilis in our surveys in the forest corridor transect, since we could readily collect these spiders in large numbers from a forest patch directly across an adjacent roadway. Furthermore, in another study, we marked $>100$ female $M$. gracilis along a 100-m-long transect towards the southern edge of the forest corridor (T.B.C. and E.A.H. unpubl. data). Therefore, while Micrathena and related spiny orb-weavers are hypothesized to have antipredator defenses against muddauber wasps, we were not able to directly address this since these wasps and spiders rarely overlapped in our study areas.

That being said, we observed $C$. californicum attempting to sting and capture female $M$. gracilis in field enclosures on three separate occasions (T.B.C. pers. obs.). These interactions were brief (several seconds at most) and afterwards the wasp flew away. Female M. gracilis were unharmed in all cases-they continued 
moving normally on their webs after being attacked by the wasp. It is possible that wasps unsuccessfully attempted to sting $M$. gracilis in their sclerotized opisthosomas, although mud-dauber wasps are known to sting spiders in the ventral prosoma (O'Neill 2001). Female M. gracilis rapidly flick their prosoma while stridulating (T.B.C. and E.A.H. unpubl. data), which could make the prosoma a more difficult target to sting. The vibrations generated through stridulation could additionally function by startling and/or warning signaling towards wasps (Masters 1979). Regardless, multiple traits may interact to generate antipredator defenses against mud-dauber wasps in female $M$. gracilis and other spiny orb-weavers (Magalhães and Santos 2012). We suggest that experimental additions of focal traits (e.g., spines) to known spider prey that lack them (e.g., Argiope spp.) will better allow us to disentangle if and how individual traits contribute to defense against mud-dauber wasps.

We found that by late July, many nests contained developing mud-dauber wasps, the majority of which were pupating. This timing is similar to the phenology of mud-dauber wasps reported from other studies in the continental United States (Rau 1915), and we could not discern any differences in phenology between $S$. caementarium and $C$. californicum. We found more developing mud-dauber wasps per nest from agricultural lands than in forests. This enhances the trend that wasps in agricultural regions collect more spiders, since the majority of these developing wasps had consumed all of the spiders provisioned to their individual cells. Unfortunately, this means that we could not count and identify those spiders. One nest contained 22 pupating wasps (Fig. 1b), so well over 100-if not several hundred-spiders could have been provisioned to that nest, which we cannot account for (Coudrain et al. 2013, Coville 1987). Future inventories in our geographic area should begin earlier in the reproductive season, ideally once wasps are known to emerge from diapause, in order to collect more identifiable spiders from mud nests. This will provide more precise measurements of spider prey diversity and abundance, and allow for better estimates of the impact of wasp predation on spider communities. Such studies will inform how predation risk for spiders can fluctuate in response to wasp phenology, and how local prey availability may affect wasp provisioning behavior.

The nest parasites that we found-dermestid beetles, Melittobia spp. wasp larvae, and cuckoo wasps-have been reported in other studies of mud-dauber wasps (Brockmann 1980, Coudrain et al. 2013). We found dramatically higher proportions of parasitized nests from our smaller sample of nests from the 2019 reproductive season. This high frequency of parasitism is in line with prior studies, which have reported well above half of sampled nests being parasitized by Melittobia spp. wasp larvae alone, in addition to other parasites (Coudrain et al. 2013). This difference in the frequency of nest parasitism that we observed across our sampling years could be due to the differences in the timing with which we sampled nests (late July through early August in 2018, early September in 2019). Therefore, more controlled sampling across a wider time span would not only help refine our understanding of how wasp predation impacts spider communities, but also the potential impacts of nest parasitism on mud-dauber wasp behavior.

We did not find any significant differences in spider population density across regions. This suggests that the differences in prey capture by mud-dauber wasps across regions may not be driven by differences in prey availability, and provides 
more evidence that these wasps may be more productive on agricultural lands than in forests. However, spider population density could differ across sites at the family level, which we cannot resolve with our current data set. Therefore, differences in mud-dauber wasp prey capture could reflect differences in the local abundance of preferred spider prey (Powell and Taylor 2017), which future studies could address in more detail. Such work also would add to the literature addressing how agricultural activity and land management strategies influences spider community composition (e.g., Birkhofer et al. 2008, Chapman et al. 2013, Sunderland and Samu 2000).

\section{Acknowledgments}

We are indebted to the private property owners who welcomed us into their woods, fields, barns, sheds, and homes as we collected mud-dauber wasp nests. We thank the members of the Hebets Lab for reviewing this manuscript, especially J. Colton Watts who provided thoughtful feedback on many versions of this manuscript. We thank Caleb Frew for providing us with ample building materials for concocting muddauber wasp nesting substrate. Our work was supported by funding from the National Science Foundation Graduate Research Fellowship Program (T.B.C.), an American Arachnological Society Student Research Grant (T.B.C.), and the University of Nebraska-Lincoln UCARE Program (E.A.). We thank Sara Hartzell, Aaron Drury, and the staff at the Wilderness Park Greenways Station (Lincoln Parks \& Recreation) for allowing us to survey at the station, and set up field enclosures in the area. We thank Max Headlee and Dr. Todd Blackledge for sharing their wisdom in working with mud-dauber wasps with us. We are indebted to Daniel Schoenberg, who made building field enclosures and any associated wasp-contraptions possible, and whose enthusiasm for science and willingness to share his many skills continues to be an inspiration.

\section{References Cited}

Biere, J.M. and G.W. Uetz. 1981. Web orientation in the spider Micrathena gracilis (Araneae: Araneidae). Ecology 62(2): 336-344.

Birkhofer, K.E., E. Gavish-Regev, K. Endlweber, Y.D. Lubin, K. von Berg, D.H. Wise and S. Scheu. 2008. Cursorial spiders retard initial aphid population growth at low densities in winter wheat. Bull. Entomol. Res. 98: 249-255.

Blackledge, T.A., J.A. Coddington and R.G. Gillespie. 2003. Are three-dimensional spider webs defensive adaptations? Ecol. Lett. 6: 13-18.

Blackledge, T.A. and K.M. Pickett. 2000. Predatory interactions between mud-dauber wasps (Hymenoptera, Sphecidae) and argiope (Araneae, Araneidae) in captivity. J. Arachnol. 28(2): 211-216.

Bohart, R.M. and A.S. Menke. 1976. Sphecid Wasps of the World. A Generic Revision. Univ. California Press, Berkeley.

Brockmann, H.J. 1980. Diversity in the nesting behavior of mud-daubers (Trypoxylon politum Say; Sphecidae). Fla. Entomol. 63(1): 53-64.

Brodie Jr., E.D., B.J. Ridenhour and E.D. Brodie III. 2002. The evolutionary response of predators to dangerous prey: Hotspots and coldspots in the geographic mosaic of coevolution between garter snakes and newts. Evolution 56(10): 2067-2082.

Camillo, E. 2002. The natural history of the mud-dauber wasp Sceliphron fistularium (Hymenoptera: Sphecidae) in southeastern Brazil. Rev. Biol. Trop. 50(1): 127-134.

Chapman, E.G., J.M. Schmidt, K.D. Welch and J.D. Harwood. 2013. Molecular evidence for dietary selectivity and pest suppression potential in an epigeal spider community in winter wheat. Biol. Control 65: 72-86.

Coudrain, V., F. Herzog and M.H. Entling. 2013. Effects of habitat fragmentation on abundance, larval food, and parasitism of a spider-hunting wasp. PLoS ONE 8(3): e59286. 
Coville, R.E. 1987. Spider-hunting sphecid wasps, Pp. 309-318. In Nentwig, W. (ed.), Spider Ecophysiology. Springer-Verlag, Heidelberg.

Coward, S.J. and R.W. Matthews. 1995. Tufted titmouse (Parus bicolor) predation on muddauber wasp prepupae (Trypoxylon politum). J. Kans. Entomol. Soc. 68(3): 371-373.

Crawford, R.L. 1986. Spider prey of the mud-dauber, Sceliphron caementarium (Sphecidae) in Washington. Proc. Wash. State Entomol. Soc. 48: 797-800.

Dean, D.A., M. Nyffeler and W.L. Sterling. 1988. Natural enemies of spiders: Mud dauber wasps in East Texas. Southwest. Entomol. 13(4): 283-290.

Dorris, P.R. 1969. Spiders collected from mud-dauber nests in Clark County, Arkansas. Proc. Ark. Acad. Sci. 23: 88-90.

Eberhard, W.E. 1970. The predatory behavior of two wasps, Agenoideus humilis (Pompilidae) and Sceliphron caementarium (Sphecidae), on the orb weaving spider Araneus cornutus (Araneidae). Psyche 77(2): 243-251.

Elgar, M.A. and M. Jebb. 1999. Nest provisioning in the mud-dauber wasp Sceliphron laetum (F. Smith): Body mass and taxa specific prey selection. Behaviour 136(2): 147-159.

Gathmann, A. and T. Tscharntke. 2002. Foraging ranges of solitary bees. J. Anim. Ecol. 71: 757-764.

Gonzaga, M.O. and J. Vasconcellos-Neto. 2005. Orb-web spiders (Araneae: Araneomorphae; Orbiculariae) captured by hunting-wasps (Hymenoptera: Sphecidae) in an area of Atlantic Forest in south-eastern Brazil. J. Nat. Hist. 39(31): 2913-2933.

Gonzales-Bustamante, L. 1994. Micrathena spp. (Araneida: Araneidae), presa preferida por Sceliphron sp. (Hymenoptera: Sphecidae) en Pilcopata (Cusco). Rev. Peru. Entomol. 36: 22.

Hodge, M.A. 1987. Macrohabitat selection by the orb weaving spider, Micrathena gracilis. Psyche 94: 347-361.

Horton, C.C. and D.H. Wise. 1983. The experimental analysis of competition between two syntopic species of orb-web spiders (Araneae: Araneidae). Ecology 64: 929-944.

Hunt, J. 1993. Survivorship, fecundity, and recruitment in a mud dauber wasp, Sceliphron assimile (Hymenoptera: Sphecidae). Ann. Entomol. Soc. Am. 86(1): 51-59.

Jocqué, R. 1988. The prey of the mud-dauber wasp, Sceliphron spirifex (Linnaeus) in Central Africa. Newsl. Br. Arachnol. Soc. 51: 7.

Kurczewski, F.E. 2003. Reuse of old Trypoxylon politum nest by Chalybion californicum (Hymenoptera: Sphecidae) in New York, U.S.A. Entomol. News. 114(5): 241-245.

Large, S.I. and D.L. Smee. 2013. Biogeographic variation in behavioral and morphological responses to predation risk. Oecologia 171: 961-969. doi: 10.1007/s00442-012-2450-5.

Masters, W.M. 1979. Insect disturbance stridulation: Its defensive role. Behav. Ecol. Sociobiol. 5: 187-200.

Magalhães I.L.F. and A.J. Santos. 2012. Phylogenetic analysis of Micrathena and Cahetacis spiders (Araneae: Araneidae) reveals multiple origins of extreme sexual size dimorphism and long abdominal spines. Zool. J. Linnean. Soc. 166: 14-53.

Muma M.H. and W.F. Jeffers. 1945. Studies of the spider prey of several mud-dauber wasps. Ann. Entomol. Soc. Am. 38: 245-255.

Navarrete, S.A. and T. Manzur. 2008. Individual- and population-level responses of a keystone predator to geographic variation in prey. Ecology 89(7): 2005-2018.

Obin, M.S. 1982. Spiders living at wasp nesting sites: What constrains predation by muddaubers? Psyche 89: 321-335.

O'Neill, K.M. 2001. Solitary Wasps: Behavior and Natural History. Comstock Publishing Associates, Ithaca, NY.

Osorio, D.M and M. Vorobyev. 2005. Photoreceptor spectral sensitivities in terrestrial animals: Adaptations for luminance and colour vision. Proc. R. Soc. B: Biol. Sci. 272: 1745-1752.

Peckham, G.W. and E.G. Peckham. 1898. On the instincts and habits of the solitary wasps. Wis. Geol. Nat. Hist. Surv. Bull. 2 Sci. Ser. 1: 1-245. 
Polidori, C., M. Federici, C. Pesarini and F. Andrietti. 2007. Factors affecting spider prey selection by Sceliphron mud-dauber wasps (Hymenoptera: Sphecidae) in northern Italy. Anim. Biol. 57(1) :11-28.

Polidori, C., L. Trombino and C.F.F. Andrietti. 2005. The nest of the mud-dauber wasp, Sceliphron spirifex (Hymenoptera, Sphecidae): Application of geological methods to structure and brood cell contents analysis. Ital. J. Zool. 72: 153-159.

Powell, E.C. and L.A. Taylor. 2017. Specialists and generalists coexist within a population of spider-hunting mud dauber wasps. Behav. Ecol. 28(3): 890-898. doi: 10.1093/beheco/ arx050.

Ramirez, M.G. and K.E. Haakonsen. 1999. Gene flow among habitat patches on a fragmented landscape in the spider Argiope trifasciata (Araneae: Araneidae). Heredity 83: 580-585.

Rau, P. 1915. The number of generations per year of the mud-daubers (Hymen.). Entomol. News 26(10): 469-471.

Rau, P. 1928. The nesting habits of the wasp, Chalybion caeruleum. Ann. Entomol. Soc. Am. 21: 25-35.

Rau, P. 1935. The spider prey of the mud wasp, Sceliphron caementarium (Araneae, Hymenoptera: Sphecidae). Entomol. News 46: 267-270.

Reeve, J.D., B.L. Strom, L.K. Rieske, B.D. Ayres and A. Costa. 2009. Geographic variation in prey preference in bark beetle predators. Ecol. Entomol. 34: 183-192. doi: 10.1111/j/ 1365-2311.2008.01055.x.

Shafer, G.D. 1949. The Ways of the Mud-Dauber. Stanford Univ. Press, Stanford, CA.

Simpfendorfer, C.A., A.B. Goodreid and R.B. McAuley. 2001. Size, sex and geographic variation in the diet of the tiger shark, Galeocerdo cuvier, from Western Australian waters. Environ. Biol. Fishes 61: 37-46.

Sunderland, K. and F. Samu. 2000. Effects of agricultural diversification on the abundance, distribution, and pest control potential of spiders: A review. Entomol. Exp. Appl. 95: 1-13.

Terraube, J. and B. Arroyo. 2011. Factors influencing diet variation in a generalist predator across its range distribution. Biodivers. Conserv. 20: 2111-2131. doi: 10.1007/s10531011-0077-1.

Toja, H. and T. Sota. 2006. Imbalance of predator and prey armament: Geographic clines in phenotypic interface and natural selection. Am. Nat. 167(1): 105-117.

Ubick, D., P. Paquin, P.E. Cushing and V. Roth (eds.). 2005. Spiders of North America: An Identification Manual. American Arachnological Society, Middleton, $\mathrm{OH}$.

Uma, D.B., C. Durkee, G. Herzner and M. Weiss. 2013. Double deception: Ant-mimicking spiders elude visually- and chemically-oriented predators. PLoS ONE 8(11): e79660. doi: 10.1371/journal.pone.0079660.

Uma, D.B. and M.R. Weiss. 2009. Chemical mediation of prey recognition by spider-hunting wasps. Ethology 116: 85-95. doi: 10.1111/j/1439-0310.2009.01715.x.

Volkova, T., R.W. Matthews and M.C Barber. 1999. Spider prey of two mud dauber wasps (Hymenoptera: Sphecidae) nesting in Georgia's Okefenokee Swamp. J. Entomol. Sci. 34(3): 322-327. 